Volume 9, Issue 1 (Winter 2017)

\title{
Rembrandt and Hals Visit the Arundel Collection
}

Paul Crenshaw

paul.crenshaw@providence.edu

Recommended Citation:

Paul Crenshaw, "Rembrandt and Hals Visit the Arundel Collection," JHNA 9:1 (Winter 2017) DOI: 10.5092/jhna.2017.9.1.7

Available at https://jhna.org/articles/rembrandt-hals-visit-arundel-collection/

Published by Historians of Netherlandish Art: https://hnanews.org/

Republication Guidelines: https://jhna.org/republication-guidelines/

Notes: This PDF is provided for reference purposes only and may not contain all the functionality or features of the original, online publication. This PDF provides paragraph numbers as well as page numbers for citation purposes.

ISSN: 1949-9833 


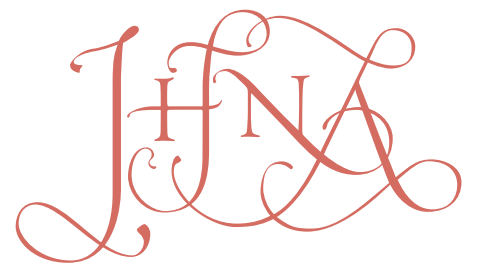

JOURNAL OF HISTORIANS OF NETHERLANDISH ART

REMBRANDT AND HALS VISIT THE ARUNDEL COLLECTION

\section{Paul Crenshaw}

On the basis of a tight timeline of opportunity and visual comparisons between paintings, it is suggested that certainly Rembrandt and likely Frans Hals visited the Arundel collection around the year 1652, and were particularly influenced by portraits of Lord and Lady Guildford, among the many works by Hans Holbein in the collection. Connections are drawn to Rembrandt's 1652 Large Self-Portrait in Vienna and to Hals's likely pendant portraits of a woman in the Frick Collection and a man in the Metropolitan Museum of Art. D01:10.5092/jhna.2017.9.1.7

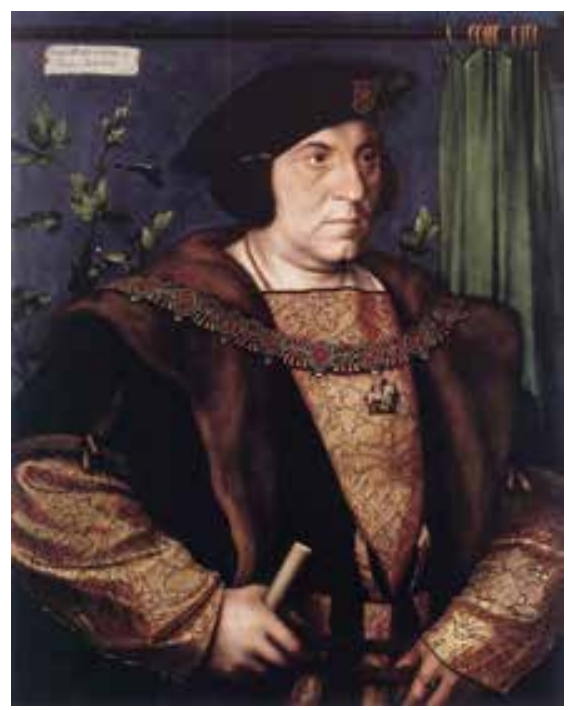

Fig. 1 Hans Holbein, Portrait of Lord Guildford, 1527, oil on panel, $82.7 \times 66.4 \mathrm{~cm}$. Windsor Castle, Royal Collection, inv. RCIN 400046 (artwork in the public domain)

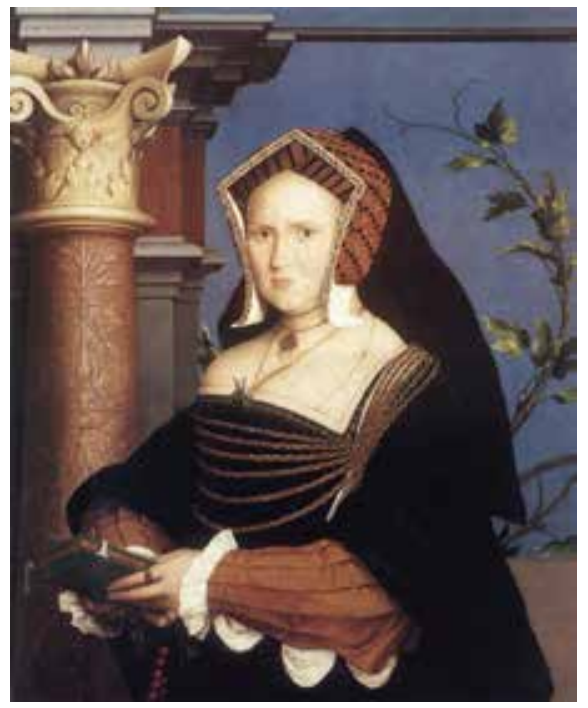

Fig. 2 Hans Holbein, Portrait of Lady Guildford, 1527, oil on panel, $87 \times 70.6 \mathrm{~cm}$. St. Louis Art Museum, Museum Purchase, inv. 1:1943 (artwork in the public domain)

1 We take it as axiomatic that early modern artists visited local collections to view and discuss works with patrons and with their peers. Evidence of this practice can be culled from various tidbits, including biographical accounts such as Arnold Houbraken's claim that Govaert Flinck was on such friendly terms with the de Graeff family that he would stop over on Sundays unannounced. ${ }^{1}$ We have no reason to doubt that such visits happened with great regularity, but specific evidence is slender enough that any time we can document a particular case it is welcome. This 
brief paper proposes, on the basis of a tight timeline of opportunity and visual similarities among several paintings, that almost certainly Rembrandt and possibly Frans Hals visited the famous Arundel collection in or just before the year 1652, and in particular that both were drawn to pendant portraits by Hans Holbein representing Lord and Lady Guildford (figs. 1 and 2), among the many Holbein paintings that were featured there.

2 One of the greatest collections of art and antiquities of the seventeenth century was amassed by Thomas Howard (1586-1646), the twenty-first Earl of Arundel, and his wife Alatheia Talbot (1585-1654). ${ }^{2}$ The collection was vast, including dozens of fine examples of ancient statuary and more than a hundred marble busts, and paintings by Hans Holbein, Adam Elsheimer, Daniel Mytens, Peter Paul Rubens, and Gerrit van Honthorst. Howard commissioned portraits of himself and his family from Mytens, Rubens, Jan Lievens, and Anthony van Dyck. He also collected drawings by Leonardo da Vinci, Holbein, Raphael, Parmigianino, Dürer, and others, along with hundreds of important manuscripts. While Lord Arundel is usually credited with the formation of the collection while serving as special envoy of Charles I to various European courts, it should be borne in mind that the couple's joint wealth was due to Talbot's inheritance of vast estates and the concomitant income. ${ }^{3}$ This paper will focus primarily on Lady Arundel, because if the premise is correct that Rembrandt and Hals paid a visit to see this collection in 1652, she would have been the host, as Howard had already passed away and had no influence on its display in Amsterdam. There is ample reason to believe that she was practiced in such engagements with artists and highly knowledgeable about the collection.

3 Lady Arundel's wealth enabled the couple to buy back Arundel House in London and, while she was dissuaded from accompanying the earl on many of his diplomatic journeys, she did accompany him on long travels in 1613-14 that took them to the Continent, first as far as Heidelberg in the company of Princess Elizabeth Stuart on her marriage to the Elector Palatine Frederick V, and then to Italy, along with the architect and designer Inigo Jones. This grand tour of Italian cities, and Paris on the return trip, laid the foundation of their prized possessions, and shortly after their return her inheritance of one-third of her father's estate enabled them to collect on an even more ambitious level.

4 In 1619 Lady Arundel traveled without her husband to Antwerp, where she and her retinue, including Sir Dudley Carleton, then ambassador to Holland, were painted by Peter Paul Rubens (today in the Alte Pinakothek, Munich). This grand portrait, showing her seated on an outdoor portico with a sweeping tapestry and panorama, Solomonic columns, and expensive accouterments, affords her the same prominence as many European monarchs. She then set off for Italy. After visiting Milan and Padua, she settled for several years in Venice, but political intrigue led her to move on, in 1623, to Turin and Mantua, accompanied by van Dyck, and to return home via Ghent.

In 1641, as the couple was preparing to leave England due to the political turmoil that would lead to the Civil War, Lady Arundel took an inventory of her possessions at their second home, Tart Hall on the Thames, just south of Buckingham Palace. This collection included a kunstkamer referred to as the "Dutch Pranketing Room." ${ }^{3}$ While she and her husband were supposed to accompany the French regent Marie de Médicis to the Continent, they left in advance of the entourage, 
traveling first to Utrecht, before rejoining main party and going to Cologne. In 1642 Howard was part of the entourage of Princess Mary when she married William II of Orange. Due to the tumultuous politics he never returned to England, instead moving to Antwerp and then finally to a villa near Padua. He died there in 1646.

6 Although she had planned to accompany her husband to Italy, Lady Arundel remained in the Dutch Republic, living first in a country house in Amersfoort, near that of Elizabeth, queen of Bohemia. Later she moved to Amsterdam, where she lived on the Singel until her death on June 4,1654 . We know that she entertained intellectuals and artists there, including the antiquarian Sir Edward Walker (1611-1677) and the engraver and still-life painter Hendrik van der Borcht (1583-1651). She was frequently visited at this time by Franciscus Junius (1591-1677), who earlier had served as the Arundels' librarian in England. ${ }^{5}$ Joachim von Sandrart, who had visited Arundel House in 1627, described the fabulous gardens filled with ancient statuary and marveled at the Old Master paintings. Pertinent to this paper, Sandrart remarked especially on the "superlative excellence of the works of Hans Holbein." ${ }^{\prime}$ An inventory totaling 799 items was taken of the Amsterdam possessions in 1655. Interestingly, unlike the 1641 inventory from Tart Hall where none of the pictures were attributed, the Amsterdam inventory separated the vast number of prized pictures with attributions from the other curiosities in the collection.

Let us turn now to the potential visits by Rembrandt and Hals; the proposal that they visited Lady Arundel is based on specific visual similarities between works known to have been in the Arundel collection and some of the works produced by these two artists in or around 1652. While one could undertake an expansive look at this topic, this paper will focus on the Holbein pendants of Lord and Lady Guildford mentioned at the beginning. Certainly these two Dutch artists would have been drawn to the numerous Holbein portraits amidst the many treasures in the Arundel household, and some suggestions will be made here as to relationships found among other paintings as well.

8 The Holbein portrait of Lady Guildford and Frans Hals's Portrait of a Woman in the Metropolitan Museum from the early 1650s (fig. 3) bear a remarkable resemblance in pose, tenor, and the physical stature of the woman portrayed. The background columns, generally regarded as symbolic of fortitude, would seemingly secure the relationship between the two works, except for one nagging problem: we cannot be entirely certain when the background elements were added. The Met painting has a likely pendant, Portrait of an Artist (fig. 4), located just down the street from the Met in the Frick Collection, that likewise has a column in the background. The two paintings, despite being in close proximity today, have been separated since the early eighteenth century. The paintings are approximately the same size, both having been slightly trimmed in the past. The columns do not exactly accord with one another, but that degree of variation between pendants is not uncommon generally speaking, or in Hals's work in particular. In fact, the backgrounds of Holbein pendants often differ from the male to the female portrait. The problem comes in the technical analysis, which suggests that the backgrounds were originally painted monochromatically, before the columns were added in a second stage. Walter Liedtke deemed the inclusion of the columns "unsympathetic." If it were merely a matter of the background elements being a slightly later addition, one might suggest that the painter in the Frick portrait was the one who added them. 


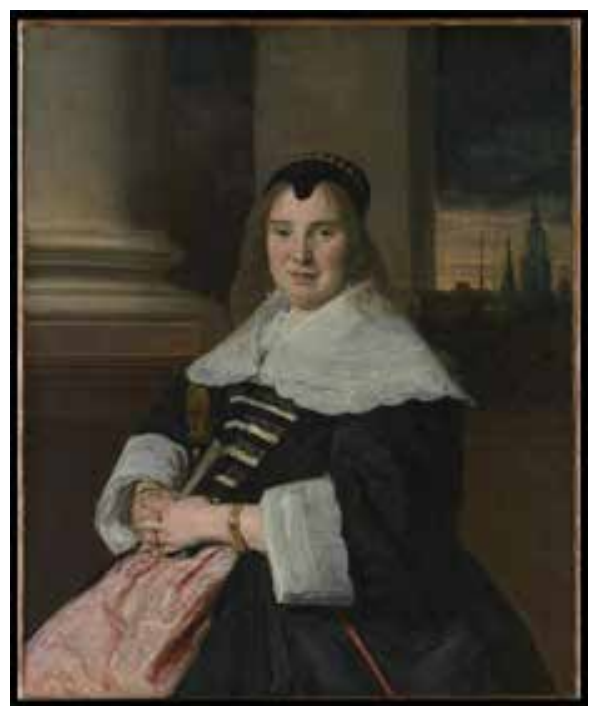

Fig. 3 Frans Hals, Portrait of a Woman (Judith Leyster?), ca. 1652 , oil on canvas, $100 \times 81.9 \mathrm{~cm}$. New York, The Metropolitan Museum of Art, Gift of Henry G. Marquand, 1890, inv. 91.26 .10 (artwork in the public domain).

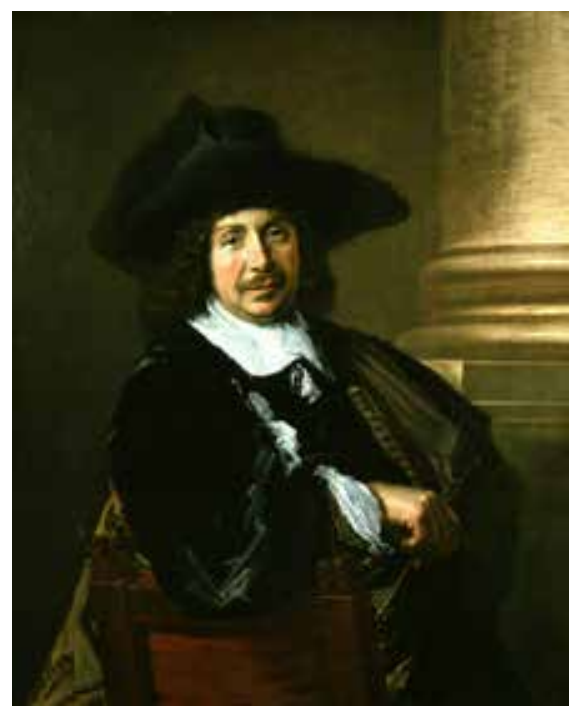

Fig. 4 Frans Hals, Portrait of a Painter (Jan Miense Molenaer?), ca. 1652 , oil on canvas, $100.3 \times 82.9 \mathrm{~cm}$. New York, The Frick Collection, Henry Clay Frick Bequest, inv. 1906.1.71 (artwork in the public domain)

Alternatively, as this author explored in a paper presented at the College Art Association conference and will more fully examine in a forthcoming publication, it is quite possible that the woman represented here was also a painter, none other than Judith Leyster. ${ }^{9}$ The man's portrait then would be identifiable as her husband, the painter Jan Miense Molenaer. ${ }^{10}$ It is beyond the scope of this paper to fully explore, but if this is correct, one might wonder if Molenaer and Leyster also visited the Arundel Collection with Hals.

That said, there is another technical finding that casts doubt on whether the backgrounds could have been painted by Hals, Molenaer, or Leyster. The two columns, in the man's portrait and in the woman's, and the background cityscape, contain the pigment Naples yellow (lead antimonate yellow). This pigment was widely used in Italy but was evidently little known in Northern European painting before the eighteenth century, although it can be found in Dutch majolica. Joris Dik has noted that analytical difficulties with various forms of lead antimonate make it possible that more paintings will be discovered to have used it, but until such confirmation exists one must conclude that almost certainly these elements of Hals's pictures were added at a later point, presumably to update the taste to lighten the background and appear more classicizing. ${ }^{11}$ It is tempting to think that whoever added the columns may well have known the Holbein Guildford portraits and recognized the relationship, but such an assertion is far too tenuous. Obviously without the columns one cannot be as confident that the Hals was directly inspired by the Holbein, but nonetheless the similarity in the bearing of the two women is striking. While Lady Guildford holds a book and the woman in the Hals portrait tightly clasps her hands, the remainder of the poses are very much in accord. Such three-quarter turned, half-length poses are not uncommon, but the dignified rendering of a woman of some girth, enabled by the scale of the figure in the painting, the turn of the head, the angle of the shoulders, the flattening of the forefront bend in the arm, and the foreshortening of the rear arm are all tightly aligned and relatively unusual. 


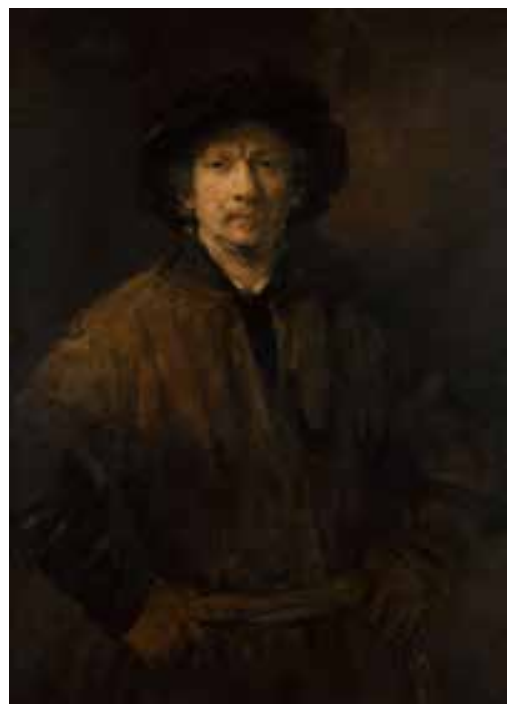

Fig. 5 Rembrandt, Large Self-Portrait, 1652, oil on canvas, $112 \times 8.15 \mathrm{~cm}$. Vienna, Kunsthistorisches Museum, Gemäldegalerie, inv. 411 (artwork in the public domain)

11 Rembrandt likely saw these Holbein portraits in the Arundel collection as well, and very likely in the year 1652. Lord Guildford's pose with both elbows akimbo but the body turned slightly in space so that one shoulder and elbow pull forward was not so unusual among Holbein's English portraiture. Rare, however, is the manner in which Lord Guildford places his thumbs in his belt. Rembrandt employed the same gesture in his Vienna Large Self-Portrait of 1652 (fig. 5). The pose with both elbows akimbo is unprecedented for Rembrandt. The plane of the shoulders turned slightly in space mirrors the Holbein, and the extremely rare detail of the thumbs in the belt seems to secure the connection. One should not underestimate Rembrandt's ability to come up with such uncommon features on his own, but the timing of the pictures with the presence of the Arundel paintings in Amsterdam seems more than coincidental.

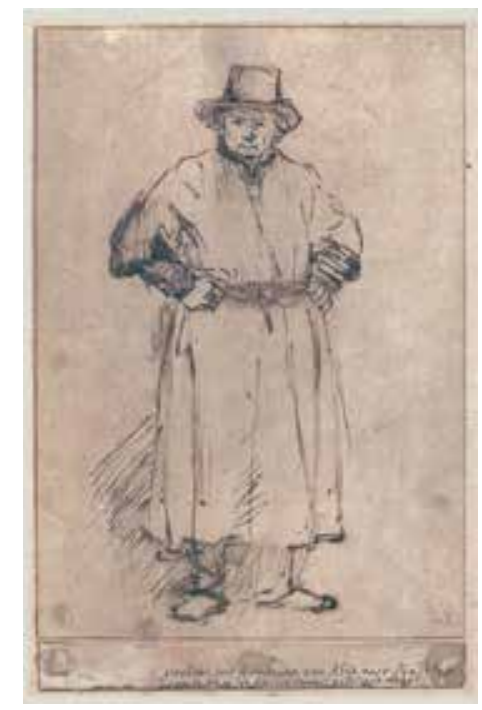

Fig. 6 Rembrandt (?), Full-Length Self-Portrait, 1652, pen and brown ink, $20.3 \times 13.4 \mathrm{~cm}$. Amsterdam, Museum het Rembrandthuis (artwork in the public domain)

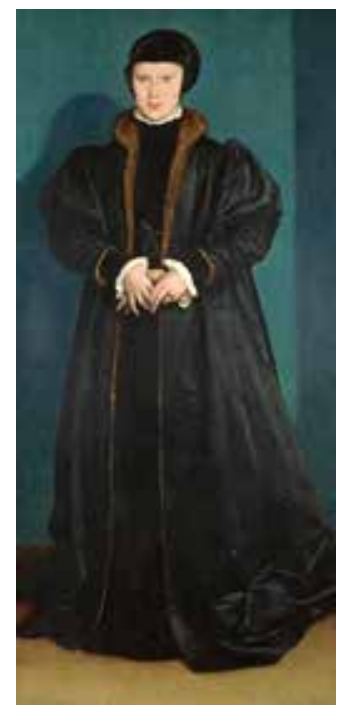

Fig. 7 Hans Holbein, Portrait of Christina of Denmark, Duchess of Milan, 1538, oil on panel, $179.1 \times 82.6 \mathrm{~cm}$. London, National Gallery, inv. NG2475 (artwork in the public domain)

12 A drawing related to Rembrandt's Vienna Large Self-Portrait exists in the Rembrandthuis (fig. 6), 
although its attribution to the master himself has been challenged and its purposed debated in a recent volume of the Rembrandt Corpus. ${ }^{12}$ Here, unlike Lord Guildford, Rembrandt is seen in full-length. One wonders if the drawing (or at least the pose and composition that lay behind it) might have been inspired in part by the Guildford precedent and in part by another Holbein in the Arundel collection, the Portrait of Christina of Denmark, Duchess of Milan (fig. 7). The duchess is also shown full-length, and while her elbows extend out they are not formally akimbosuch poses were considered more aggressive and masculine, connoting a sense of superiority or nonchalance. Similar to Rembrandt's drawing is also the silhouette of her long cloak. Rembrandt too wears a nearly full-length working cloak in the drawing. Again, while Rembrandt could easily have come to the idea of a full-length pose simply by looking in a mirror on his own, and they are fairly common in portraiture generally, fully frontal poses with extended elbows and full-length garments are more exceptional.

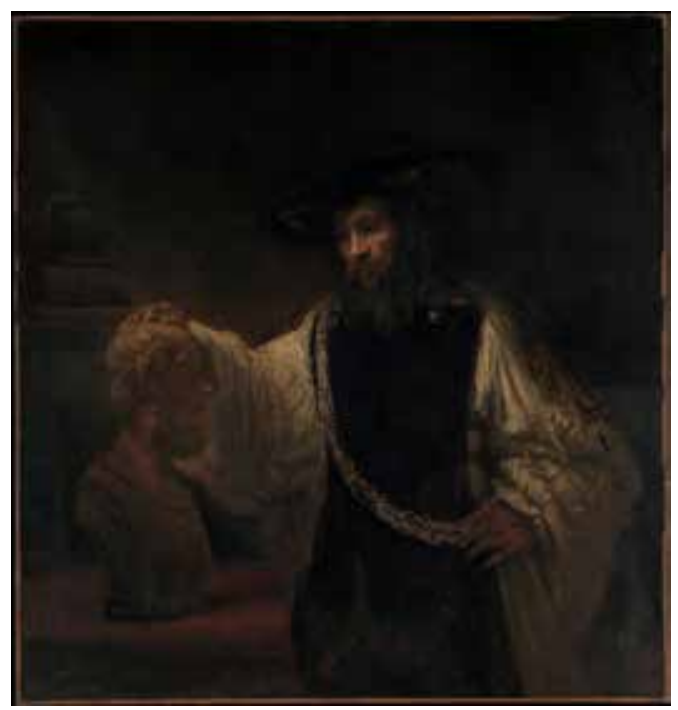

Fig. 8 Rembrandt, Aristotle with a Bust of Homer, 1653, oil on canvas $143.5 \times 136.5 \mathrm{~cm}$. New York, Metropolitan Museum of Art, iinv. 61.198 (artwork in the public domain)

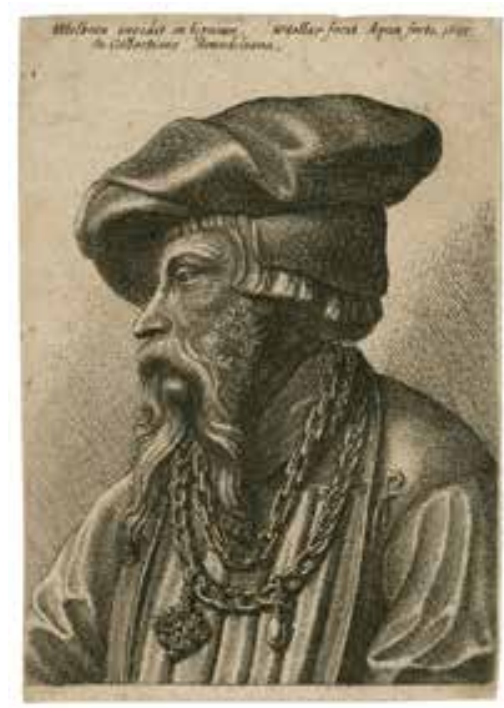

Fig. 9 Wenzel Hollar, after Hans Holbein, Portrait of a Man with a Beard, Beret, and Chain, 1647, etching. Amsterdam, Rijksmuseum (artwork in the public domain)

13 Lastly, Rembrandt carried the detail of the thumbs, taken from Guildford and used in his Self-Portrait, to another painting in the Metropolitan Museum, the Aristotle with a Bust of Homer from 1653 (fig. 8). Here the principle figure also places a finger, not in his belt, but in the chain of honor that diagonally straddles his torso. There is yet another Holbein from the Arundel collection that may have lingered in Rembrandt's thoughts, a painting apparently now lost but known from a print made in 1647 by Wenzel Hollar (fig. 9). The image represents a bearded man in profile with a heavy chain and a prominent jeweled cross dangling at the chest.

14 Given that such images were reproduced with inscriptions designating their collections, one could extend the consideration further and ponder to what extent such correspondences were meant to be recognized by patrons of Hals and Rembrandt and their audiences. The role of artistic emulation and recognition in circles of collecting is a very large topic, also beyond the scope of this article, but recent research in this area suggests that it was an essential aspect of the social engagement with images. ${ }^{13}$ 
15 Such visits to collections served artists in more ways than merely stimulating their own inventions. They were opportunities for discourse and to win the affections of new patrons. The Arundel inventory of 1655 lists no works by Hals, but five by Rembrandt (spelled alternately Rynbrandt and Ryndbrandt). These were:

small man's head ("testa d'home in piccolo")

St. John (“St. Gioanni”)

woman with a kid and a child ("Donne con capretto et faciullo")

portrait of a man praying ("ritratto d'homo pregando")

an old man drawn by Rembrandt ("un homo vecchio disegnato de Ryndbrandt")

16 It is difficult to ascertain from the entries whether the first four were paintings, prints, or drawings; the last seems to be a drawing; although the description technically could translate as a work designed by Rembrandt and executed by someone else, this is not the normal manner of indicating such a situation. If these were works on paper, they were presumably framed and hung on the walls. The Arundels actually owned very few works by contemporary Dutch artists; the collection consisted primarily of older works and some by contemporary Flemish artists. It is impossible to know when and where they acquired their Rembrandts, but it is not unlikely that the acquisition was the product of a visit rather than a prelude to one. It is also possible that Rembrandt offered Lady Arundel a gift, or even a package of his work, particularly given that one of the works is designated as small (i.e., a tronie).

17 While one cannot reconstruct the dialogue that must have occurred when an artist of the stature and ingenuity of a Frans Hals or a Rembrandt visited a treasured collection such as the one built and enjoyed by Lady Arundel, it stimulates the imagination to great wonderment. What if Rembrandt and Hals were there together? It is unlikely, of course, but just another reminder that we have no direct documentary connection between these two towering contemporaries in Dutch art. At the very least, the prospect of a possible encounter with the Arundel collection provides fodder for fuller considerations of Rembrandt and Hals amidst this wider circle of humanists and international tastemakers.

Paul Crenshaw is an associate professor and chair of the Department of Art and Art History at Providence College in Providence, Rhode Island. He is currently vice-president of the Historians of Netherlandish Art. His articles, exhibitions and books on Dutch and Italian art of the early modern period include Rembrandt's Bankruptcy (Cambridge University Press, 2006).

paul.crenshaw@providence.edu

\section{Acknowledgments}

I would like to thank the staffs at the Frick Collection, the Metropolitan Museum of Art, and the 
St. Louis Art Museum for their assistance with this material, as well as the anonymous reviewer for the JHNA who provided insightful feedback.

\section{List of Illustrations}

Fig. 1 Hans Holbein, Portrait of Lord Guildford, 1527, oil on panel, 82.7 x $66.4 \mathrm{~cm}$. Windsor Castle, Royal Collection, inv. RCIN 400046 (artwork in the public domain)

Fig. 2 Hans Holbein, Portrait of Lady Guildford, 1527, oil on panel, 87 x $70.6 \mathrm{~cm}$. St. Louis Art Museum, Museum Purchase, inv. 1:1943 (artwork in the public domain)

Fig. 3 Frans Hals, Portrait of a Woman (Judith Leyster?), ca. 1652, oil on canvas, $100 \times 81.9 \mathrm{~cm}$. New York, The Metropolitan Museum of Art, Gift of Henry G. Marquand, 1890, inv. 91.26.10 (artwork in the public domain).

Fig. 4 Frans Hals, Portrait of a Painter (Jan Miense Molenaer?), ca. 1652, oil on canvas, $100.3 \mathrm{x}$ $82.9 \mathrm{~cm}$. New York, The Frick Collection, Henry Clay Frick Bequest, inv. 1906.1.71 (artwork in the public domain)

Fig. 5 Rembrandt, Large Self-Portrait, 1652, oil on canvas, 112 x $8.15 \mathrm{~cm}$. Vienna, Kunsthistorisches Museum, Gemäldegalerie, inv. 411 (artwork in the public domain)

Fig. 6 Rembrandt (?), Full-Length Self-Portrait, 1652, pen and brown ink, 20.3 x $13.4 \mathrm{~cm}$. Amsterdam, Museum het Rembrandthuis (artwork in the public domain)

Fig. 7 Hans Holbein, Portrait of Christina of Denmark, Duchess of Milan, 1538, oil on panel, 179.1 x $82.6 \mathrm{~cm}$. London, National Gallery, inv. NG2475 (artwork in the public domain)

Fig. 8 Rembrandt, Aristotle with a Bust of Homer, 1653, oil on canvas $143.5 \mathrm{x} 136.5 \mathrm{~cm}$. New York, Metropolitan Museum of Art, iinv. 61.198 (artwork in the public domain)

Fig. 9 Wenzel Hollar, after Hans Holbein, Portrait of a Man with a Beard, Beret, and Chain, 1647, etching. Amsterdam, Rijksmuseum (artwork in the public domain)

\footnotetext{
${ }^{1}$ Arnold Houbraken, De Groote Schouburgh der Nederlandtsche Konstschilders en Schilderessen (Amsterdam: Weduwe Houbraken, 1718-21), 2:18.

${ }^{2}$ Literature on the Arundel collection is vast, but especially good are the studies of David Howarth, including "The Arundel Collection: Collecting and Patronage in England in the Reigns of Philip III and Philip IV," in The Sale of the Century: Artistic Relations Between Spain and Great Britain, 1604-1655, exh. cat., ed. Jonathan Brown and Jonathan Elliot (New Haven: Yale University Press, 2002), 69-86.

${ }^{3}$ A convenient reference with relevant literature on Lady Arundel is Michelle DiMeo, "Howard,
} 
Aletheia, Countess of Arundel, of Surrey, and of Norfolk, and suo jure Baroness Furnivall, Baroness Talbot, and Baroness Strange of Blackmere (d. 1654)," in Oxford Dictionary of National Biography (Oxford: Oxford University Press, 2004); online ed., January 2008, ed. Lawrence Goldman. http://www.oxforddnb.com/view/article/94252 (accessed December 14, 2015). ${ }^{4}$ Juliet Claxton, “The Countess of Arundel's Dutch Pranketing Room," Journal of the History of Collections 22, no. 2 (November 2010): 187-96; first published online August 17, 2009. http:// dx.doi.org/10.1093/jhc/fhp035

${ }^{5}$ On Junius, see, most recently, Thijs Weststeijn, Art and Antiquity in the Netherlands and Britain: The Vernacular Arcadia of Franciscus Junius (1591-1677) (Leiden: Brill, 2015). http://dx.doi. org/10.1163/9789004283992

${ }^{6}$ Joachim von Sandrart, Teutsche Academie der Edlen Bau-Bild- und Mahlerey-Künste, vol. 2 (Nuremberg, 1675). On Arundel hosting artists in England, see Craig Ashley Hanson, The English Virtuoso: Art, Medicine and Antiquarianism in the Age of Empiricism (Chicago: University of Chicago Press, 2009), 24ff; and Christiane Hille, Visions of the Courtly Body: The Patronage of George Villiers, First Duke of Buckingham, and the Triumph of Painting at the Stuart Court (Berlin: Walter de Gruyter, 2012), 20-24. http://dx.doi.org/10.18820/9781920338367 http://dx.doi. org/10.1524/9783050062556

${ }^{7}$ The 1655 inventory was published in Lionel Cust and Mary L. Cox, "Notes on the Collections Formed by Thomas Howard, Earl of Arundel and Surrey, K.G., Burlington Magazine 19, no. 101 (August 1911): 278-86. The beginning of the inventory was mistakenly omitted from the original publication and published subsequently. See Mary L. Cox, "Inventory of the Arundel Collection," Burlington Magazine 19, no. 102 (September 1911): 323-25.

${ }^{8}$ Walter Liedtke. Dutch Paintings in the Metropolitan Museum of Art (New York: Metropolitan Museum of Art/New Haven: Yale University Press, 2007), 1:ix, 295-98, no. 68, color pl. 68, fig. 80. ${ }^{9}$ Paul Crenshaw, "Frans Hals's Portrait of an Older Judith Leyster," College Art Association Annual Conference, Chicago, February 10-13, 2010. The papers from this session on "Old Women, Witches and Old Wives" and additional ones will be published together, edited by Frima Fox Hofrichter.

${ }^{10}$ The identification of Molenaer is easier, as the likeness to his many visages in his genre paintings is keen. The likeness of the Met's portrait to Leyster's Self-Portrait in Washington, D.C. (National Gallery of Art) is more problematic, but one must remember that the National Gallery's painting was created twenty years earlier, before Leyster had experienced five pregnancies.

${ }^{11}$ Joris Dik, "Scientific Analysis of Historical Paint and the Implications for Art History and Art Conservation: The Case Studies of Naples Yellow and Discoloured Smalt," PhD thesis (Van 't Hoff Institute for Molecular Sciences [HIMS], University of Amsterdam, 2003), esp. chap. 2, confirmed earlier studies concluding that lead antimonate yellow was exceedingly rare in seventeenth-century Dutch painting, but, curiously, he did find it present in pottery samples from Holland at this time (p. 31).

${ }^{12}$ Van de Wetering, Ernst, et al. A Corpus of Rembrandt Paintings IV (Dordrecht: Springer, 2005), 413-15.

${ }^{13}$ See for example Elizabeth Cropper, The Domenichino Affair: Novelty, Innovation and Theft in Seventeenth Century Rome (New Haven: Yale University Press, 2005), esp. chap. 3, "Imitation, Influence, Invention: The Carracci and Tasso"; Maria Loh, Titian Remade: Repetition and the Transformation of Early Modern Italian Art (Los Angeles: Getty Publications, 2007); and Eric Jan Sluijter, Rembrandt's Rivals: History Painting in Amsterdam (1630-1650) (Amsterdam and Phila- 
delphia: John Benjamins, 2015). http://dx.doi.org/10.1075/oculi.14

\section{Bibliography}

Claxton, Juliet. “The Countess of Arundel's Dutch Pranketing Room." Journal of the History of Collections 22, no. 2 (November 2010): 187-96. First published online August 17, 2009. http:// dx.doi.org/10.1093/jhc/fhp035

Cust Lionel, and Mary L. Cox. "Notes on the Collections Formed by Thomas Howard, Earl of Arundel and Surrey, K.G." Burlington Magazine19, no. 101 (August 1911): 278-86.

Cox, Mary L. "Inventory of the Arundel Collection." Burlington Magazine 19, no. 102 (September 1911):. 323-25.

Crenshaw, Paul. "Frans Hals's Portrait of an Older Judith Leyster." Paper presented at the College Art Association Annual Conference, Chicago, February 10-13, 2010.

Cropper, Elizabeth. The Domenichino Affair: Novelty, Innovation and Theft in Seventeenth Century Rome. New Haven: Yale University Press, 2005.

Dik, Joris. "Scientific Analysis of Historical Paint and the Implications for Art History and Art Conservation: The Case Studies of Naples Yellow and Discoloured Smalt." PhD thesis, Van 't Hoff Institute for Molecular Sciences (HIMS), University of Amsterdam, 2003.

DiMeo, Michelle. "Howard, Aletheia, Countess of Arundel, of Surrey, and of Norfolk, and suo jure Baroness Furnivall, Baroness Talbot, and Baroness Strange of Blackmere (d. 1654)." In Oxford Dictionary of National Biography. Oxford: Oxford University Press, 2004. Online ed., edited by Lawrence Goldman, January 2008. http://www.oxforddnb.com/view/article/94252

Hanson, Craig Ashley. The English Virtuoso: Art, Medicine and Antiquarianism in the Age of Empiricism. Chicago: University of Chicago Press, 2009. http://dx.doi.org/10.18820/9781920338367

Hille, Christiane. Visions of the Courtly Body: The Patronage of George Villiers, First Duke of Buckingham, and the Triumph of Painting at the Stuart Court. Berlin: Walter de Gruyter, 2012. http:// dx.doi.org/10.1524/9783050062556

Houbraken, Arnold. De Groote Schouburgh der Nederlandtsche Konstschilders en Schilderessen. Amsterdam: Weduwe Houbraken, 1718-21.

Howarth, David. "The Arundel Collection: Collecting and Patronage in England in the Reigns of Philip III and Philip IV." In The Sale of the Century: Artistic Relations Between Spain and Great Britain, 1604-1655, exh. cat., edited by Jonathan Brown and Jonathan Elliot, 69-86. New Haven: Yale University Press, 2002.

Liedtke, Walter. Dutch Paintings in the Metropolitan Museum of Art . 2 vols. New York: Metropoli- 
tan Museum of Art/New Haven: Yale University Press, 2007.

Loh, Maria. Titian Remade: Repetition and The Transformation of Early Modern Italian Art. Los Angeles: Getty Publications, 2007.

Sandrart, Joachim von. Teutsche Academie der Edlen Bau-Bild- und Mahlerey-Künste . ., vol. 2. Nuremberg, 1675.

Sluijter, Eric Jan. Rembrandt's Rivals: History Painting in Amsterdam (1630-1650). Amsterdam and Philadelphia: John Benjamins , 2015. http://dx.doi.org/10.1075/oculi.14

Weststeijn, Thijs. Art and Antiquity in the Netherlands and Britain: The Vernacular Arcadia of Franciscus Junius (1591-1677) . Leiden: Brill, 2015. http://dx.doi.org/10.1163/9789004283992

Recommended Citation:

Paul Crenshaw, "Rembrandt and Hals Visit the Arundel Collection,"JHNA 9:1 (Winter 2017), D0I: 10.5092/jhna.2017.9.1.7 